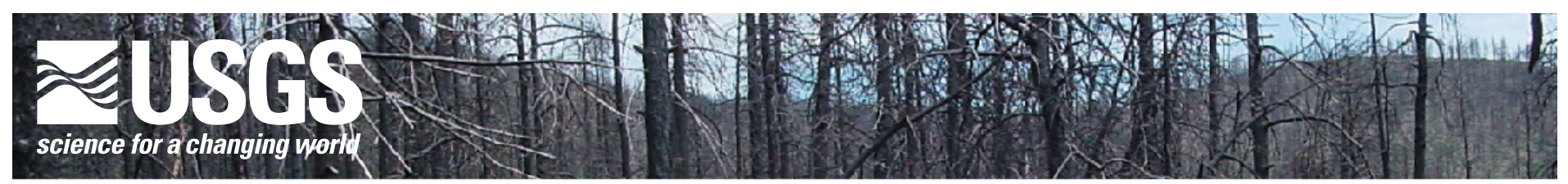

\title{
Communicating with Wildland Interface Communities During Wildfire
}

\section{Issues}

Communications during fire events are complex. Nevertheless, training fire information officers to plan fire communications before events, and to communicate during fires in a way that accurately and promptly informs residents in fire-affected areas, can increase effectiveness, reduce anxiety, ensure residents have accurate information on which to act, help them make better decisions, and possibly save lives.

\section{What We Did}

What information do people need, and when? U.S. Geological Survey (USGS) scientists Jonathan Taylor and Shana Gillette were part of an interagency team, including Ron Hodgson of the Bureau of Land Management (BLM) and Judith Downing of the USDA Forest Service, that investigated this question. The team examined the information-seeking behavior of residents during a wildfire event to guide more effective agency communication practices with the public. The researchers employed "quick-response research" (interviewing residents before, during, and following a fire event) to study fire communications. Studies

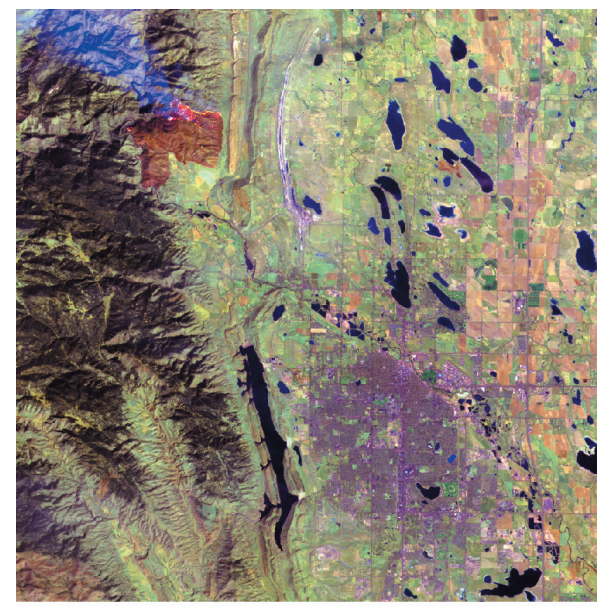

Picnic Rock Fire (upper left in image) near Fort Collins, Colorado. USGS Landsat photo. were conducted in the fall of 2003 during a small fire (Bridge Fire) and before, during, and after an extreme fire event (Old and Grand Prix Fires) in the San Bernardino Mountains of southern California. Pre-fire communication preparations were also evaluated.

\section{What We Learned}

\section{- People told us that they urgently sought real-time information when wildfire threatened their communi- ties. They wanted information to help them take actions to protect their families and property and to make sense out of what was happening.}

\section{- Media and official information} sources seldom provided the kind of information residents wanted where and when it was useful. Residents said television news from the scene was often inaccurate and seemed to focus on the more spectacular aspects. Official information often came too late and was not specific enough about the threat to their neighbohoods.
(Requirements for information verification and release appear to have delayed dissemination of official information.)

\section{- Community residents did not wait} for official or mass media information. They actively searched for information anywhere they could find it and from anyone who had it. They listened to scanners, talked to firefighters they knew, went to see for themselves. Effective, informal information networks quickly developed. Residents produced their own news and communicated it to their neighbors in person or via cell phone, e-mail, Web sites, and other communication channels.

\section{Recommendations}

- Give real-time information. To be effective, information on wildlandurban interface (WUI) fires needs to be timely, accurate, and useful in helping communities cope effectively with the fire threat.

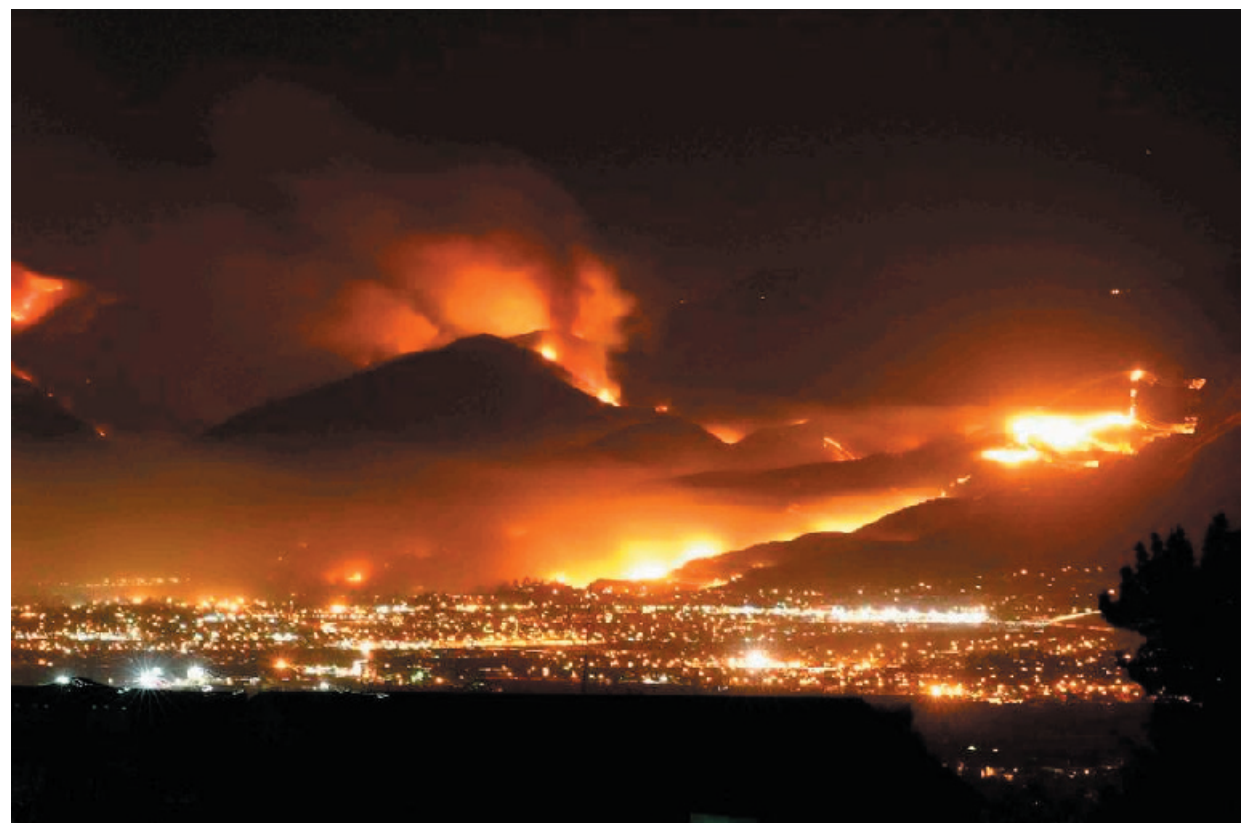

Old Fire above the city of San Bernardino, California, 2003. Photo courtesy of Chris Doolittle. 
- Inform the networks. WUI communities are served by relatively complex information networks that go well beyond traditional media (broadcast television, commercial radio, and newspaper). Residents are becoming producers of news through the use of digital technology such as cell phones and the Internet.

- Plan for re-entry and reoccupation. A communication plan and methods for re-entry to the area and reoccupation of homes and businesses are as important as plans for evacuation.

\section{- Plan for information flow during} transitions. The information flow to the public needs to be carefully maintained when there are transitions between fire teams and between stages of a fire event. Additionally, information flow should be re-evaluated between fire events to reflect changing conditions and community needs.

- Incorporate community agencies and organizations into information dissemination. Community agencies, organizations, and trained residents can help augment official information functions by providing local expertise and serving as informational links to local informal networks.

\section{Science Impact}

BLM and Forest Service partners are sharing findings from the study with fire managers, information officers, and agency public affairs officers, who in turn are incorporating the findings into fire information-officer training and other forums. Implementation of these findings at multiple levels within agencies can directly enhance agency communication with WUI communities before, during, and after a wildfire event.

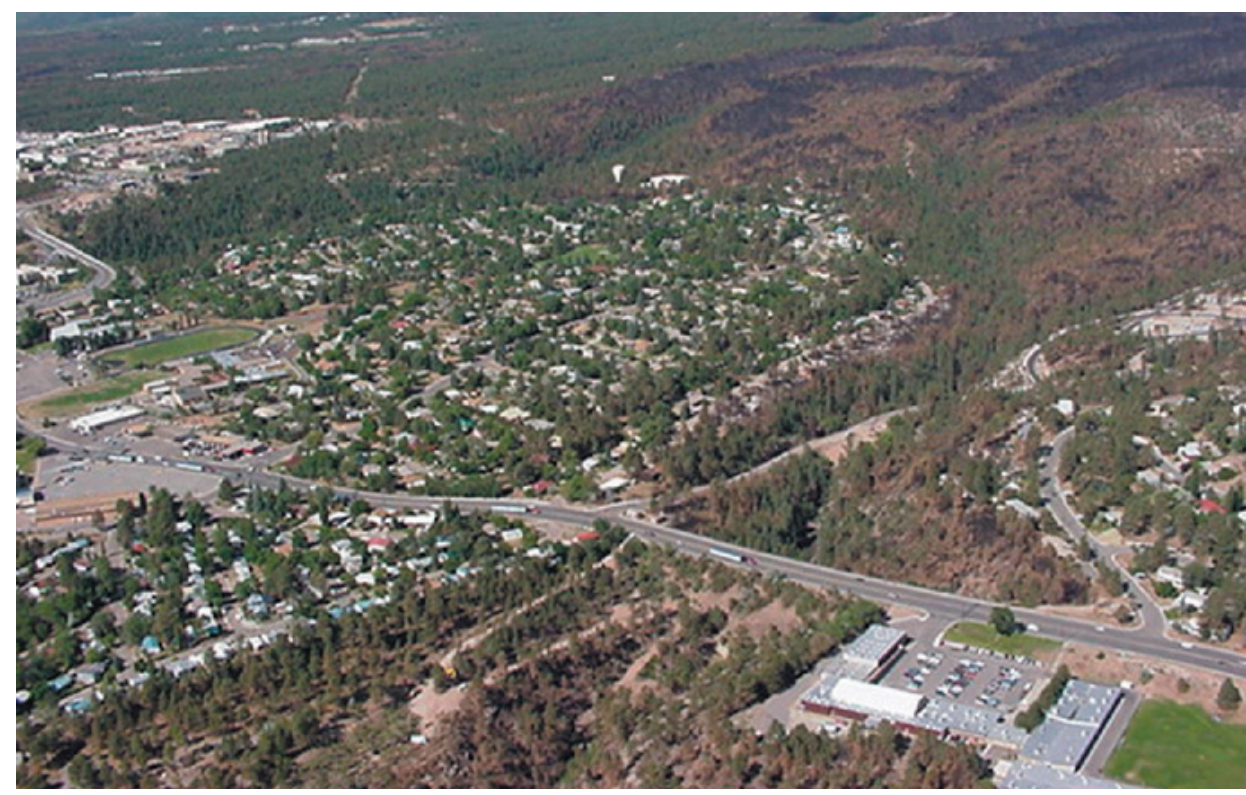

A fire-affected wildland-urban interface community: Los Alamos, New Mexico. The burned areas (brown) are from the Cerro Grande Fire of 2000.

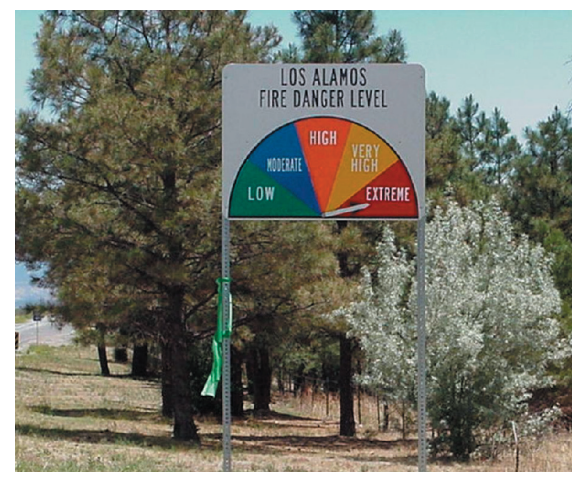

Fire danger sign, Los Alamos, New Mexico.

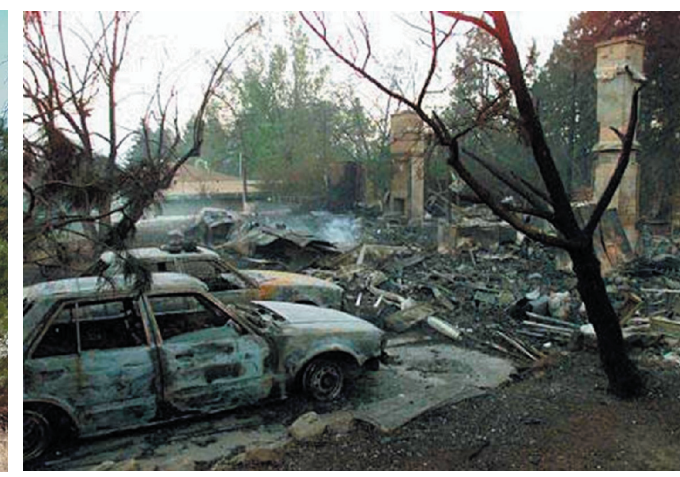

Property damage from the Cerro Grande Fire, Los Alamos, New Mexico.

\section{For More Information}

\section{Jonathan Taylor}

USGS Fort Collins Science Center 2150 Centre Avenue, Building C Fort Collins, CO 80526-8118

Tel. 970-226-9438

Fax $970-226-9230$

E-mail: jonathan_taylor@usgs.gov

\author{
Shana Gillette \\ USGS Fort Collins Science Center \\ 2150 Centre Avenue, Building $C$ \\ Fort Collins, CO 80526-8118 \\ Tel. 970-226-9308 \\ Fax 970-226-9230 \\ E-mail: shana_gillette@usgs.gov
}

For the full report, see Taylor, J.T., S.C. Gillette, R.W. Hodgson, and J.L. Downing. 2005. Communicating with wildland interface communities during wildfire. USGS Open File Report 2005-1061. Available online at www.fort.usgs.gov/products/publications/21411/21411.asp 